\title{
Notice of disputed authorship to: Vitamin C supplementation reconstitutes polyfunctional $T$ cells in streptozotocin-induced diabetic rats
}

\author{
Gamal Badr • Samir Bashandy - Hossam Ebaid • \\ Mohamed Mohany $\cdot$ Douaa Sayed
}

Published online: 14 June 2012

(c) Springer-Verlag 2012

\section{Notice of disputed authorship to: Eur J Nutr DOI 10.1007/s00394-011-0176-5}

European Journal of Nutrition and its editorial staff are deeply committed to publishing integrity and follow the guidelines of the Committee on Publication Ethics (COPE) and therefore are obliged to inform the readership about the continuous authorship dispute pertaining this article. Specifically, Dr. Saleh Alwasel's name was excluded at the proof correction stage by the corresponding author, Dr. Gamal Badr. Dr. Alwasel contacted the publisher when he found the article published online first without his name on it. The publisher asked the authors to solve this dispute and included the COPE recommendations on settling author disputes for their advice, but unfortunately, an amicable agreement could not be reached until now. The publisher and editorial staff of the European Journal of Nutrition are not in a position to settle this conflict, but feel impelled to inform the readers about the status quo.

On behalf of the journal's editorial staff:

Gerhard Rechkemmer, Editor-in-Chief

The online version of the original article can be found under doi:10.1007/s00394-011-0176-5.

G. Badr $(\bowtie) \cdot$ S. Bashandy $\cdot$ H. Ebaid $\cdot$ M. Mohany

Zoology Department, College of Science, King Saud University,

P.O. Box 2455, Riyadh 11451, Saudi Arabia

e-mail: badr73@yahoo.com

G. Badr

Fetal Programming of Diseases Research Chair,

College of Science, King Saud University,

Riyadh, Saudi Arabia

G. Badr

Zoology Department, Faculty of Science, Assiut University,

Assiut, Egypt

D. Sayed

Clinical Pathology Department, South Egypt Cancer Institute,

Assiut University, Assiut, Egypt 